\title{
ANTÓNIO MACHADO GUERREIRO UM HOMEM DE EQUIPA, LÍDER E FORMADOR
}

JORGE GASPAR ${ }^{1}$

O Dr. António Machado Guerreiro foi um dos "fundadores" e suporte fundamental da afirmação do Centro de Estudos Geográficos enquanto instituição de referência no panorama da investigação científica em Portugal nos após guerras.

A sua actividade no CEG repartiu-se por múltiplos domínios, da manutenção da "infra-estrutura" ao apoio em diferentes fases do processo do trabalho científico dos investigadores do CEG.

Um homem sempre em progresso, sabendo adaptar-se e adequar-se a cada período da sua vida e da vida das instituições, por isso deu, ao longo de mais de quatro décadas, contributos oportunos e relevantes.

Conhecedor dos comportamentos humanos, encontrou sempre o caminho da convivência e da utilidade. Por isso ganhou tantos amigos, sem prejudicar ou provocar alguém; por isso não terá tido inimigos.

Quero aqui relevar uma faceta menos realçada: António Machado Guerreiro era um homem de equipa, integrando-se no trabalho colectivo, da contabilidade e gestão corrente ao trabalho científico, sob múltiplos aspectos - aqueles em que era solicitado ou em que ele se sentiria mais útil.

E homem de equipa, também ao nível da liderança e da formação.

Assim, António Machado Guerreiro fez tanta coisa e tão bem feita, porque pôde contar com excelentes colaboradores que ele, de uma maneira ou de outra, com maior ou menor influência, ajudou a formar.

Lembrar aqui os nomes desses colaboradores directos da "infra-estrutura" de apoio do CEG, que tão relevantes serviços prestaram, é não só uma forma de os homenagear e lembrar como o CEG lhes é devedor, mas também de homenagear, de forma superlativa, António Machado Guerreiro.

De memória, procurando seguir a rota do tempo (sem prejuízo da relevância de cada um) e ressalvando desde já erros e lacunas, aparecem-me os seguintes nomes:

António Agostinho - o outro Machado Guerreiro, para mim, o primeiríssimo discípulo do mestre, merecedor de várias homenagens. O Centro e muitos dos que com ele conviveram, só poderemos lastimar a falta de oportunidades que lhe deveriam ter sido concedidas, para que nos pudesse ter ajudado ainda mais...

1 Professor Catedrático aposentado da Faculdade de Letras da Universidade de Lisboa. Investigador do Centro de Estudos Geográficos. E-mail: jgaspar@fl.ul.pt 
Mário Rito, o primeiro dos "miúdos" que entraram no Centro e que muito graças ao encaminhamento de António Machado Guerreiro, saíram homens...Saiu, mas está sempre a visitar-nos, ao longo destas já mais de 4 décadas, o que mostra que deixou amigos.

Rita Caldas, que provou que as pessoas que trabalham em colectivo não precisam de ser formatadas e que a liberdade dá quase sempre os melhores dividendos. Foi à sua vida - pois o CEG sempre teve dificuldade em dar horizontes largos às pessoas que os desejavam e tantas vezes mereciam.

O mui saudoso António Feliciano Baltazar, que o professor Orlando Ribeiro "trouxe" de Curvel, concelho de Torres Vedras, em 1962. Homem de múltiplas habilidades, o que lhe permitia colaborar com toda a gente, sem nunca perder aquele fantástico sorriso, foi outro discípulo de mestre Guerreiro.

Creio que na ordem cronológica se seguiu António Barreira, um transmontano, de Torre de Dona Chama, "avalizado" por Ilídio do Amaral, outro polivalente, com uma "especialização" em trabalhos de campo e que todos lembramos pela sua disponibilidade (de resto uma qualidade quase inerente a todos estes colaboradores do CEG) e boa disposição.

Conceição Figueira, que o primo António trouxe da "terra" e em boa hora. Tem sido um dos pilares do CEG, pois é sólida e exige solidez... Felizmente podemos continuar a contar com a sua colaboração...

Do mesmo modo, a Celeste Gaspar Mendes que eu levei até ao CEG e que António Machado Guerreiro recebeu, como se de mais uma sobrinha se tratasse, ficou e continua a dar hoje o seu útil contributo ao CEG.

Julieta Vivaldo, esta sobrinha de António Machado Guerreiro, cheia de personalidade, séria e amiga do Centro. Também ela não deslustrou a Escola em que se formou...

Manuel Figueiredo, outro "miúdo" da cantera, este creio que levado pela mão do Prof. Ilídio do Amaral que, claro, o depositava nas mãos do Mestre Guerreiro, como quem diz: "Aqui lhe deixo o rapaz, veja o que pode fazer por ele!" (...). E o resultado foi excelente! Tirou um curso, arrumou uma boa carreira profissional, acabando por ser tentado pela intervenção social e política, sempre com os melhores resultados.

Foi com entusiasmo e emoção que lembrei uma parte da vida do CEG, menos "pública" mas que importa enaltecer, pela importância que revestiu para o seu sucesso.

Obrigado António Machado Guerreiro. 